\title{
Early results of optimal septal myectomy using 3-dimensional printed models
}

\author{
Uladzimir Andrushchuk, Vitali Adzintsou, Artsem Niavyhlas, Hanna Model, Youry Ostrovsky \\ $2^{\text {nd }}$ Department of Cardiac Surgery, Republican Scientific and Practical Centre 'Cardiology', Minsk, \\ Republic of Belarus
}

Kardiochirurgia i Torakochirurgia Polska 2019; 16 (2): 74-80

\begin{abstract}
Introduction: The completeness of septal myectomy (SM) is the key to surgery of hypertrophic obstructive cardiomyopathy (HOCM), but its planning is still based on echocardiographic findings. The need to perform radical SM requires the development of new cardio-visualisation techniques for monitoring myectomy quality.

Aim: To improve results in centres treating few patients with HOCM using a new method of optimal SM with the help of 3-dimensional models to achieve an 'ideal' interventricular septum (IVS) thickness of 10-11 mm.

Material and methods: Between 2017 and 2018, 30 patients underwent optimal SM after computed tomography angiography, creation of a virtual 3-dimensional model of the IVS, computer-aided mapping, virtual SM and 3-dimensional printing of models of the 'ideal' IVS and the fragment to be removed.

Results: Initial isolated extended SM ( $n=29,97 \%)$ was effective in 23/29 (79\%) patients. Four non-fatal complications were observed. A permanent pacemaker was implanted in three patients. No patients required mitral valve replacement. The mean postoperative left ventricle (LV) resting systolic gradient was $7.5 \pm 4.4 \mathrm{~mm} \mathrm{Hg}$, and at the latest follow-up this value was $7.1 \pm 4.2 \mathrm{~mm} \mathrm{Hg}$. The average weight of the excised myocardium was $12.0 \mathrm{~g}$ (range: 5.8-22.5 g). At follow-up both volumetric and dimensional LV echocardiography parameters increased compared with preoperative values ( $p \leq 0.007)$.

Conclusions: The proposed optimal SM provides intraoperative monitoring of the shape and volume of the myocardium resected to achieve the 'ideal' IVS, true radicality and an increase in the volumetric and dimensional parameters of the LV.
\end{abstract}

Key words: hypertrophic obstructive cardiomyopathy, septal myectomy, 3D printing.

\section{Streszczenie}

Wprowadzenie: Miektomia septalna - miektomia przegrody międzykomorowej (SM) jest podstawową metodą leczenia kardiomiopatii przerostowej z zawężeniem drogi odpływu (HOCM), a jej planowanie wciąż opiera się na wynikach badania echokardiograficznego. Rozwój nowych metod wizualizacji serca w celu oceny rozległości mioseptektomii i monitorowania skuteczności zabiegu jest niezbędny do wykonania radykalnej SM.

Cel: Poprawa wyników leczenia w ośrodkach przyjmujących niewielu chorych z HOCM poprzez zastosowanie nowej metody optymalnej SM z wykorzystaniem modeli 3D w celu osiągnięcia pożądanej grubości przegrody międzykomorowej (IVS) - 10-11 mm.

Materiat i metody: W okresie od 2017 r. do 2018 r. u 30 pacjentów przeprowadzono optymalną SM. Wcześniej wykonano u nich tomografię komputerową z opracowaniem wirtualnych modeli IVS i mapowania komputerowego, wytworzeniem wirtualnej SM oraz druku 3D modeli IVS i fragmentu mięśnia, którego usunięcie jest konieczne do zapewnienia optymalnej grubości IVS po zabiegu.

Wyniki: Izolowana rozszerzona SM $(n=29,97 \%)$ była skuteczna u 23/29 (79\%) pacjentów. Zarejestrowano cztery powikłania niezakończone zgonem. Trzem pacjentom implantowano stymulator serca. Nie stwierdzono potrzeby wykonania plastyki zastawki mitralnej w badanej grupie chorych. Wyjściowa średnia wartość resztkowego maksymalnego skurczowego gradientu lewej komory (LV) wynosiła 7,5 $\pm 4,4 \mathrm{~mm} \mathrm{Hg}$, a w późnym okresie pooperacyjnym 7,1 $\pm 4,2 \mathrm{~mm} \mathrm{Hg}$. Średnia masa usuniętego mięśnia wynosiła 12,0 g (5,8-22,5 g). W obserwacji odległej w porównaniu z wynikami przedoperacyjnymi stwierdzono poprawę parametrów echokardiograficznych $(p \leq 0,007)$.

Wnioski: Proponowana technika optymalnej SM umożliwia uzyskanie odpowiedniego kształtu i objętości usuniętego mięśnia w celu osiągnięcia optymalnej grubości IVS, odpowiedniego stopnia radykalności oraz poprawy parametrów objętościowych i wielkościowych lewej komory.

Słowa kluczowe: kardiomiopatia przerostowa z zawężeniem drogi odpływu, miektomia przegrody międzykomorowej, druk 3D.

Address for correspondence: Uladzimir Andrushchuk PhD, Republican Scientific and Practical Centre ‘Cardiology', Minsk, Republic of Belarus, phone: +375297733158, e-mail: heartslight@mail.ru Received: 13.02.2019, accepted: 22.05.2019. 


\section{Introduction}

Hypertrophic cardiomyopathy, which is usually genetically determined, is a disease of the myocardium characterized by marked hypertrophy of the left ventricle (LV) and occasionally the right ventricle (RV), possible obstruction of the LV outflow tract (LVOT), life-threatening arrhythmia and sudden cardiac death [1]. The European Society of Cardiology (ESC) Guidelines for the diagnosis and management of hypertrophic cardiomyopathy [2] suggest surgical septal myectomy (SM) as the preferred treatment in patients with hypertrophic obstructive cardiomyopathy (HOCM). The success of SM depends on the following factors: clinic and operator experience [3], precise cardiac imaging, an accurate surgical plan and intraoperative monitoring of the results, and is defined by comparison with the target outcome. Identifying these optimal factors is a challenge for centres that perform low numbers of procedures (i.e., low-volume centres) and for surgeons inexperienced in SM. The extent of SM affects the surgical outcomes [4], but its planning is still mainly based on echocardiographic findings. According to the 2014 ESC Guidelines [2], transthoracic echocardiography (TTE) is recommended as initial evaluation for all patients with hypertrophic cardiomyopathy. Cardio-vascular magnetic resonance (CMR) or computed tomography angiography (CTA) is indicated only in those with an inadequate echocardiography window. There are few studies and limited case reports that describe the use of 3-dimensional (3D) cardiac imaging and 3D-printed models of the LV and interventricular septum (IVS) to treat patients with HOCM [5]. 3D models are useful for cardiac imaging [5] and for improving the surgeon's manual skills in performing SM [6]. We offer a new method of extended SM, namely an optimal 3D-modelled septal myectomy (OSM) [7] to achieve an 'ideal' thickness of 10-11 mm at all points of the IVS. We suggest that the OSM should not only reduce the elevated LVOT gradient and systolic anterior motion (SAM) of the mitral valve, but also lead to long-term LV remodelling with an increase in its volumetric dimensional parameters and decreased diastolic dysfunction. It should also accelerate the surgeon's learning curve.

\section{Aim}

To improve results in centres treating few patients with hypertrophic obstructive cardiomyopathy, we propose a new method of optimal septal myectomy using 3-dimensional models to achieve an 'ideal' interventricular septum thickness of $10-11 \mathrm{~mm}$ at all points.

\section{Material and methods}

Thirty consecutive patients admitted to our centre between January 2017 and July 2018 were included in this prospective non-randomized cohort study. Their dominant symptom was shortness of breath. The inclusion criterion was a peak pressure gradient in the area of LV obstruction (basal, mid-ventricular or both) $\geq 40 \mathrm{~mm} \mathrm{Hg}$ at rest and being refractory to ongoing drug therapy. Exclusion criteria were contraindications to surgery. The patients' charac- teristics before surgery are summarized in Table I. Table II presents the preoperative TTE data.

Preoperative patient examinations included TTE, CTA or CMR and coronary angiography. Intraoperatively, transoesophageal echocardiography (TEE) was performed before

Table I. Baseline clinical characteristics before surgery

\begin{tabular}{|c|c|}
\hline Variable & $N(\%)$ or mean \pm SD \\
\hline Male & $20(66.7)$ \\
\hline Age [years] & $52.1 \pm 11.3$ \\
\hline NYHA functional class II & $23(76.7)$ \\
\hline NYHA functional class III & $7(23.3)$ \\
\hline Concomitant coronary disease & $4(13.3)$ \\
\hline Concomitant organic aortic valve disease & $3(10)$ \\
\hline Ventricular septal thickness by CT [mm] & $30.1 \pm 5.8$ \\
\hline Ventricular septal thickness by TTE $[\mathrm{mm}]$ & $23.6 \pm 4.2$ \\
\hline \multicolumn{2}{|l|}{ Type of HOCM: } \\
\hline Basal & $6(20)$ \\
\hline Basal-mid-ventricular & $18(60)$ \\
\hline Mid-ventricular & $1(3.3)$ \\
\hline Diffuse & $5(16.7)$ \\
\hline \multicolumn{2}{|l|}{ LV obstruction area: } \\
\hline Outflow tract & $26(86.6)$ \\
\hline Mid-ventricular & $2(6.7)$ \\
\hline Outflow tract + mid-ventricular & $2(6.7)$ \\
\hline
\end{tabular}

CT - computed tomography, LV - left ventricle, NYHA - New York Heart Association, TTE - transthoracic echocardiography.

Table II. Transthoracic echocardiography data before operation and at the latest follow-up

\begin{tabular}{lccc} 
Variable & \multicolumn{2}{c}{$N(\%)$ or mean \pm SD } & P-value \\
\cline { 2 - 3 } & Pre-op. & Follow-up & \\
Peak systolic gradient & $81.3 \pm 27.3$ & $7.1 \pm 4.2$ & $<0.001$ \\
in obstruction area [mm Hg] & & & \\
\hline LVEDD [mm] & $26.4 \pm 5.0$ & $36.2 \pm 6.9$ & $<0.001$ \\
\hline LVESD [mm] & $46.9 \pm 5.6$ & $54.4 \pm 4.2$ & $<0.001$ \\
\hline LVEDV [ml] & $112.7 \pm 29.5$ & $124.8 \pm 32.3$ & 0.007 \\
\hline LVESV [ml] & $39.3 \pm 11.4$ & $49.4 \pm 19.2$ & 0.004 \\
\hline LVEF (Simpson, \%) & $64.5 \pm 6.6$ & $64.6 \pm 8.5$ & 0.973 \\
\hline SAM: & & & $<0.001$ \\
\hline Absence & $1(3.3)$ & $29(96.7)$ & \\
\hline Grade 1/3 & $1(3.3)$ & $1(3.3)$ & \\
\hline Grade 2/3-3/3 & $28(93.4)$ & $0(0.0)$ & \\
\hline Mitral regurgitation: & & & $<0.001$ \\
\hline Mild (1/4) & $1(3.3)$ & $14(46.7)$ & \\
\hline Moderate (2/4) & $7(23.3)$ & $16(53.3)$ & \\
\hline Moderately severe (3/4) & $17(56.7)$ & $0(0.0)$ & \\
\hline Severe (4/4) & $5(16.7)$ & $0(0.0)$ & \\
\hline
\end{tabular}

LV - left ventricle, LVEDD - left ventricle end diastolic diameter, LVEDV - left ventricle end diastolic volume, LVEF - left ventricle ejection fraction, LVESD left ventricle end systolic diameter, LVESV - left ventricle end systolic volume, LVOT - left ventricle outflow tract, SAM - systolic anterior motion. 


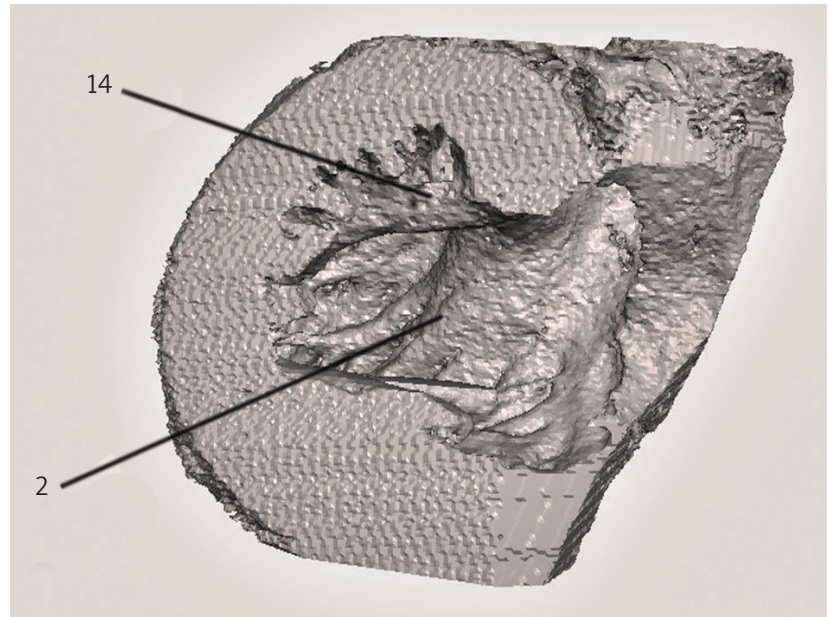

Fig. 1. Virtual 3D model of interventricular septum. Anterior bundle (1, indicated with line), posterior bundle (2, indicated with line), swallowtail bundle $(1+2$ lines)

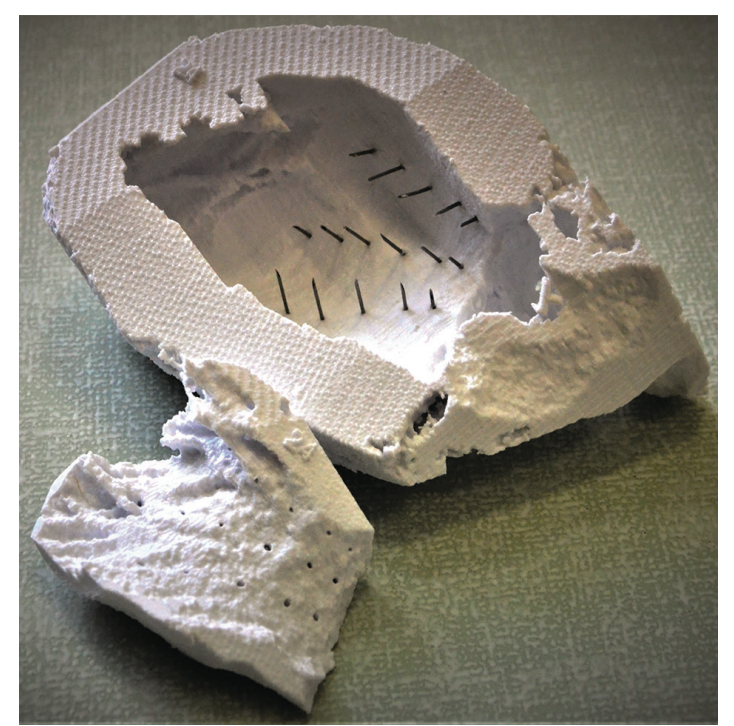

Fig. 2. Model of an 'ideal' interventricular septum with needles implanted to mark the depth of septal myectomy and the fragment to be resected

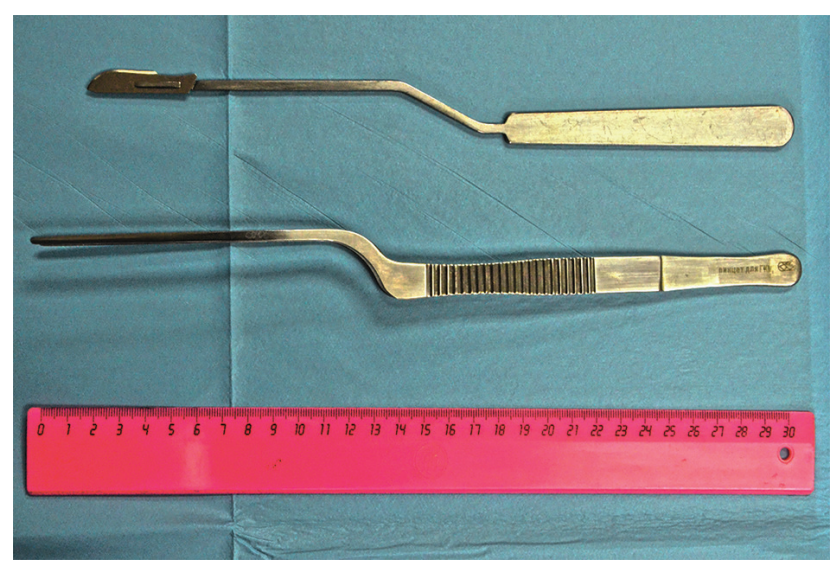

Fig. 3. Scalpel and forceps of original design used to perform 'optimal' septal myectomy and after cardio-pulmonary bypass to monitor the results of SM. Using the CTA results (cardiac diastole phase), we created a virtual 3D model of the IVS (scale $1: 1$ ) using the OsiriX open source DICOM viewer (Fig. 1). We supplemented the anatomical divisions of the IVS by adding three additional surgical zones [7, Suppplementary material] for extended SM to facilitate navigation during mapping and surgery. We distinguished three varieties of abnormal bundles: anterior, from basal segments to anterolateral papillary muscle; posterior, from basal segments to posteromedial papillary muscle, and combinations of these such as 'swallowtail' (Fig. 1). Twenty-five (83\%) patients had abnormal bundles in their LV. In three of these patients, the bundles were not visualized using TTE and TEE.

Subsequently, computer-aided mapping of the IVS was performed by cross-sectioning the 3D model in different planes and measuring the IVS thickness at different points. This was followed by performance of a virtual SM to produce an accurate plan of intervention and create an 'ideal' IVS. Virtual SM can be performed in several ways, one of which is by flattening an IVS model and then removing the flattened segment from the main model to obtain a fragment representing the tissue to be removed. The next step was 3D printing of a model of the 'ideal' IVS and its fragment in polylactide using a low-cost 3D printer (FlashForge Guider 3D printer; FlashForge Corporation, Zhejiang, China) at an average cost of $\$ 10$ per model (Fig. 2). In the first 2 cases, the fragment was excised mechanically after 3D printing. In 15 more recent cases, we implanted needles into the 'ideal' IVS to the height of the fragment to mark accurately the depth of the myocardial excision in each surgical zone (Fig. 2).

The study was approved by the ethics committee of our centre and all participants signed written informed consent.

We took a sterile 3D model to the operating room. SM was performed through an ascending aorta approach from anatomical surgical segment IA to segment IIIA [7, Suppplementary material] and from basal to apical segments. We prefer a 'layer-by-layer' excision technique. Extended SM was completed using the in-house designed scalpel and forceps (Fig. 3). In the first 15 cases, the depth of the resection in each surgical zone was determined based on the model mapping data, considering the width of a number 13 blade $(6.2 \mathrm{~mm})$ and by successively filling the surgical zones of the trough in the sterilized 3D-printed IVS model with the excised myocardium until the thickness of the excised model fragment was achieved [7]. In 15 recent cases, the excised tissue was sequentially laid out on the bottom of the 3D model until it reached the tips of the needles and then it was weighed (Fig. 4).

Abnormal muscular bundles as well as fibrous-muscular attachments between papillary muscle and IVS or LV free wall, and anomalous chordal attachments between mitral valve leaflets and IVS or LV free wall, were excised. If necessary, longitudinal incision of hypertrophic papillary muscles was also performed. 
Mortality and major hospital complications within 30 days after surgery were assessed. Follow-up examinations included symptom assessment, electrocardiography and TTE. These tests were done at discharge and at 3 and 12 months after intervention.

\section{Statistical analysis}

Continuous variables with normal distribution as indicated by the Kolmogorov-Smirnov test are reported as mean and standard deviation (mean \pm SD). These values were compared using Student's t-test or a repeated measures $t$-test. Categorical variables are presented as number and percentage. The Wilcoxon signed-rank test was used to compare repeated measurements. A statistical hypothesis of equal distributions was rejected at $p \leq 0.05$. We used SPSS software (v. 19.0; IBM Statistics, Armonk NY, USA) for all statistical analyses.

\section{Results}

The main perioperative characteristics of the participants are shown in Table III.

Initial isolated extended SM ( $n=29,97 \%)$ was effective in 23 of 29 cases (79\%). We encountered no complications when re-clamping was required (6 patients) for mitral valve interventions.

Four non-fatal complications were observed: exacerbation of chronic obstructive pulmonary disease in 1 patient and pacemaker implantation for complete atrioventricular block in 3 patients, two of whom had complete right bundle branch block before surgery. No haemodynamically significant SAM was detected. No patient required mitral valve replacement or had an iatrogenic ventricular septal defect. Six patients required a restart of cardio-pulmonary bypass when TEE monitoring revealed severe mitral regurgitation because of organic valve disease or annulus dilatation. Mitral valve repair was completed in these patients with good outcomes. In one patient, mitral valve annuloplasty was pre-planned and performed simultaneously with OSM because of severe mitral valve annulus dilatation detected on TTE. Blood regurgitation volume (calculated from TTE) in cases of residual moderate (according to the depth of the regurgitant jet into the left atrium) mitral insufficiency $(n=16,53 \%)$ did not exceed a value of $21.0 \mathrm{ml}$.

The obstruction was completely relieved in all cases, as evidenced by very low $(7.5 \pm 4.4 \mathrm{~mm} \mathrm{Hg})$ residual LVOT gradients.

In 2 patients who had extreme HOCM phenotypes with systolic sub-obliteration of the LV cavity, we resected 22.3 and $22.5 \mathrm{~g}$ of the myocardium, respectively (Fig. 4 B).

All patients underwent follow-up. The mean follow-up time was $8.8 \pm 5.5$ months (min. 9 days, max. 19 months). Complications were observed in one patient (sternal osteomyelitis). Major TTE data at follow-up are shown in Table II. Haemodynamically significant SAM was abolished in all patients. The mean resting peak LVOT gradient at the latest follow-up was $7.1 \pm 4.2 \mathrm{~mm} \mathrm{Hg}$ (min. 3, max. 15). The maximum resting peak LVOT gradient of $15 \mathrm{~mm} \mathrm{Hg}$ recorded in

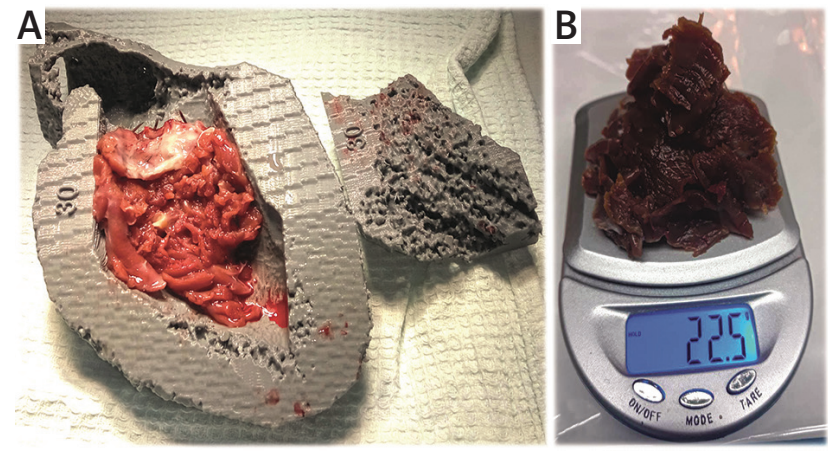

Fig. 4. A - Resected fragments of myocardium are sequentially laid out on the bottom of the 3D model until they reach the tips of the needles. B - Weighing the excised myocardium (weight in grams)

1 patient was relieved by concomitant aortic valve replacement with a 21-mm bioprosthesis because of organic aortic valve stenosis. Asymptomatic moderate (2/4) aortic regurgitation was noted in 2 patients.

Both volumetric and dimensional TTE parameters of the LV increased compared with preoperative values (Table II).

All patients are alive and show significant improvement in their quality of life. Their New York Heart Association functional class (FC NYHA) improved significantly compared with preoperative values: $70 \%$ of patients $(n=21)$ were in FC NYHA I and 30\% $(n=9)$ in FC NYHA II, $p<0.001$.

\section{Discussion}

We are convinced that the completeness of SM is of great importance and the key to surgery. Based on our experience and literature reports [8], inadequate initial SM is associated with poor outcomes. The main reasons for repeated SM in patients initially operated on for HOCM are an insufficient length of the resection towards the LV apex, inadequate depth of SM, and mid-ventricular obstruction [9].

In our clinic over the period of nine years (2007-2016) before we commenced performing OSM, only 35 (34\%) of 104 interventions were isolated SM; mitral valve replace-

Table III. Main perioperative characteristics $(n=30)$

\begin{tabular}{|c|c|}
\hline Variable & $N(\%)$ or mean \pm SD \\
\hline MV repair: & $7(23.3)$ \\
\hline Concomitant with SM & $1(3.3)$ \\
\hline Secondary (CPB restart) & $6(20)$ \\
\hline \multicolumn{2}{|l|}{ Type of MV repair: } \\
\hline Alfieri stitch & $4(13.3)$ \\
\hline Posterior semi-annulus suture plasty & $2(6.7)$ \\
\hline Carpentier ring annuloplasty & $1(3.3)$ \\
\hline Cross-clamp time [min] & $105.9 \pm 28.7$ \\
\hline Weight of resected muscle [g] & $12.0 \pm 4.2$ \\
\hline Major perioperative complications & 4 \\
\hline 30-day mortality & 0 \\
\hline Permanent pacemaker implantation & $3(10)$ \\
\hline
\end{tabular}

CPB - cardio-pulmonary bypass, MV - mitral valve, SM - septal myectomy. 


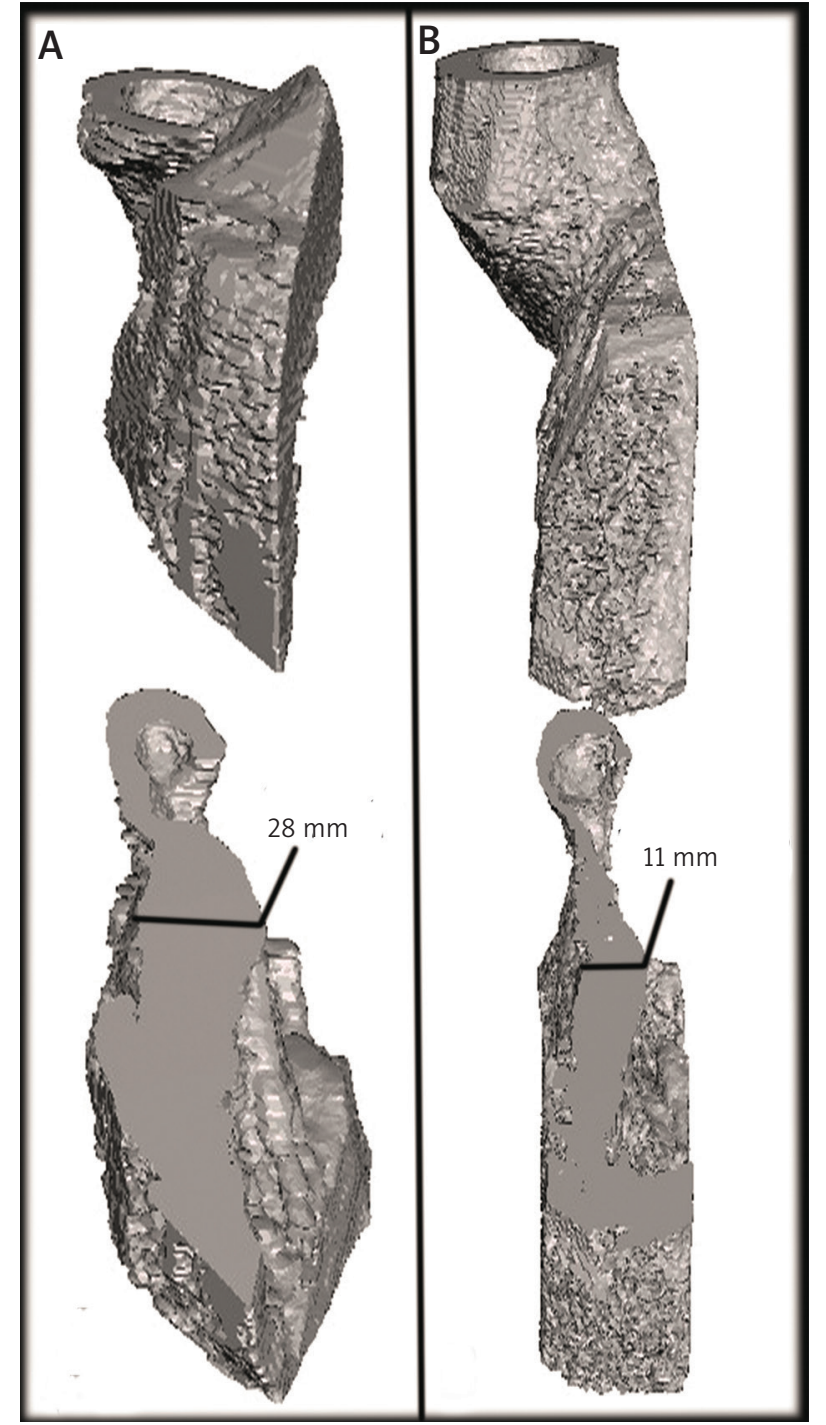

Fig. 5. A - Trans-apical section of the 3D interventricular septum model before surgery. $\mathbf{B}$ - Trans-apical section of the 3D interventricular septum model of the same patient 3 weeks after 'optimal' septal myectomy

ment (MVR) and repair made up $41.4 \%$ and $23.1 \%$, respectively (a large percentage of MVR in the surgical treatment of HOCM is generally typical of less-experienced clinics [10]). In these patients, the mean weight of the excised myocardium was only $4.7 \pm 2.9 \mathrm{~g}$, the incidence rate of iatrogenic ventricular septal defect was $7.7 \%$ and the early mortality rate was $1.9 \%$. Recurrence of symptoms and LVOT obstruction were observed in 3 patients. The difference between these results and those of the leading clinics offering HOCM surgery $[3,11]$ was catastrophic.

Such a non-radical approach was mainly because the extent of SM is currently predominantly empirical [12]. Surgeons rely on their own judgement to determine the extent of excision of the myocardium, without clear criteria for the depth, width and length of the resection. We envisage that advances in surgical procedures for HOCM will be associated with the development of new objective cardio-visu- alisation techniques for planning the shape and volume of the IVS fragment excised during SM and for intraoperative monitoring of SM quality. We believe that 2D TTE should be considered a screening method, rather than the gold standard for examining patients with HOCM. In our experience, the rejection of a preoperative 3D examination (CTA or (MR) of the heart can be a reason for inadequate $S M$ : 2D TTE underestimates IVS thickness by approximately $6.5 \mathrm{~mm}$ (23.6 \pm 4.2 vs. $30.1 \pm 5.8 \mathrm{~mm}, p<0.001$; Table I). Cardio-visualisation based on CTA or CMR plays a major role in the accurate planning of radical SM [13]. The need for accurate cardiac imaging, coupled with the aim of performing truly radical SM to achieve the 'ideal' IVS thickness (10-11 mm) at all points, led us to develop the virtual SM as a tool to allow optimal planning, not for the purpose of improving our manual skills.

A combination of factors and mechanisms contributes to developing SAM in HOCM [14]. The key to resolving SAM is to perform truly radical SM instead of abolishing the obstruction using numerous plastic mitral valve interventions as suggested by some authors [14, 15-17]. The large variety of types of mitral valve repair in HOCM only demonstrates that there is still no effective universal intervention. Only SM significantly increases the distance between the anterior mitral valve leaflet and the hypertrophied IVS [14]. Therefore, we are convinced that a truly radical SM has an advantage over partial SM combined with resection of fibrotic secondary chordae [15]. The latter can relieve LVOT obstruction at the basal segments and abolish SAM and SAM-related mitral regurgitation. However, such an approach is ineffective in cases of obstruction in the mid and apical segments, and in diffuse and extreme forms of HOCM. Trans-atrial (including minimally invasive) approaches to relieving LVOT obstruction [16-18] also do not appear promising. Their achievement of radicality is doubtful and control of the remaining IVS thickness is complicated. Relief of obstruction by suturing a large auto-pericardial patch at the base of the anterior mitral leaflet [16-19] has a highly questionable long-term prognosis for mitral valve functioning in young and middle-aged patients.

The OSM we propose involves a trans-aortic treatment of obstruction in areas up to apical segments (Fig. 5), which is enabled by the specially shaped scalpel and forceps of our own design and the resection technique we use, i.e., 'layer-by-layer' instead of 'en bloc' [20]. This technique allows a gradual improvement in visualizing IVS resection zones from basal to apical segments.

The resection topography remains clear when the fragments are laid out on the 3D-printed model. To our knowledge, the 22.3 and $22.5 \mathrm{~g}$ of myocardium that we excised in two of our patients (Fig. 4 B) are the largest excisions described in the literature. The previous largest fragment of $19.9 \mathrm{~g}$ was reported by Liu et al. in 2016 [21]. 3D reconstruction of the IVS was done in the first patient before and after the procedure and it proved the IVS thinning from 24-28 mm to 11-12 mm (Fig. 5) [7]. Further postoperative $3 \mathrm{D}$ reconstruction of the IVS was not performed because 
of optimal residual gradients and reliable TTE data on the reduced thickness of the IVS.

The radicality of OSM did not cause an increase in major in-hospital complications. Moreover, as demonstrated by our study findings, OSM resulted in positive remodelling, significantly increased volumetric and dimensional parameters, and a milder degree of diastolic dysfunction as a component of HOCM pathogenesis.

A lack of studies in the field of surgical anatomy in HOCM patients led us to develop our own anatomical-surgical classification for IVS zone resection [7], plus an anatomical-surgical classification of abnormal bundles, both of which facilitate navigation during mapping and surgery.

3D printing of an 'ideal' IVS with its excised fragment is also important in the OSM technique. One of the main problems with SM is to determine the resection depth at each point of the IVS and the thickness of the remaining IVS. This is usually done empirically based on the existing surgical plan, bimanual IVS examination [22] and different methods using ultrasonic probes [23]. We consider that none of these methods are both convenient and objective. Using sterile 3D-printed models of an 'ideal' IVS with needles implanted up to the excision height and of the IVS fragment to be removed in the operating room is an objective method of monitoring the shape, depth and volume of SM. Intraoperative weighing of the excised fragments of the hypertrophied IVS is an additional monitor of the radicality of SM and should be performed routinely. OSM does not exclude the possibility of preoperative and postoperative manual palpation of the IVS, if desired by the surgeon.

It is obvious that even the most radical SM does not allow relief of mitral regurgitation in cases of organic lesions of the mitral valve. In our practice, we had to restart cardiopulmonary bypass after OSM and TEE monitoring in six patients to allow mitral valve repair. We are now confident in the paradigm: 'Do not stitch (initially) and do not patch the mitral valve. Just do it - truly radical septal myectomy!' This method always abolishes SAM-related mitral regurgitation. In cases where mitral regurgitation remains significant owing to an organic lesion of the mitral valve, the valve can be remodelled after restarting cardio-pulmonary bypass. In our experience, moderate residual mitral regurgitation (according to the depth of the regurgitant jet into the left atrium) after initial isolated SM is asymptomatic in patients with HOCM and has no greater impact on exercise tolerance and quality of life in the long-term postoperative period than mild residual mitral regurgitation (1/4).

The pacemaker implantation rate for complete atrioventricular block after OSM does not exceed that presented in the world's largest SM registries [24, 25], but the risk of pacemaker implantation is obviously higher in patients with initial complete right bundle branch block.

Our study has some limitations, the most important of which is the small number of patients. Further patient enrolment is required to compare the results of OSM with those of other surgical treatment options for HOCM.

\section{Conclusions}

Computed tomography angiography (CMR) with 3D reconstruction is an optimal method for cardio-visualisation of the IVS. Virtual SM is an excellent planning method for a radical 3D-modelled SM. The proposed optimal 3D-modelled SM allows intraoperative monitoring of the shape and volume of the myocardium resection to achieve the 'ideal' IVS and true radicality. It eliminates obstruction in the LV and SAM, resulting in LV remodelling with an increase in LV end-diastolic volume and diameter at early follow-up. In addition, this method speeds up the learning curve for surgeons inexperienced in SM.

\section{Disclosure}

The authors report no conflict of interest.

\section{References}

1. Maron MS, Olivotto I, Betocchi S, Casey SA, Lesser JR, Losi MA, Cecchi F, Maron BJ. Effect of left ventricular outflow tract obstruction on clinical outcome in hypertrophic cardiomyopathy. N Engl J Med 2003; 348: 295-303.

2. Elliott PM, Anastasakis A, Borger MA, Borggrefe M, Cecchi F, Charron P, Hagege AA, Lafont A, Limongelli G, Mahrholdt H, McKenna WJ, Mogensen J, Nihoyannopoulos P, Nistri S, Pieper PG, Pieske B, Rapezzi C, Rutten FH, Tillmanns C, Watkins H. 2014 ESC Guidelines on diagnosis and management of hypertrophic cardiomyopathy: the Task Force for the Diagnosis and Management of Hypertrophic Cardiomyopathy of the European Society of Cardiology (ESC). Eur Heart J 2014; 35: 2733-2779.

3. Dearani JA, Ommen SR, Gersh BJ, Schaff HV, Danielson GK. Surgery insight: septal myectomy for obstructive hypertrophic cardiomyopathy - the Mayo Clinic experience. Nat Clin Pract Cardiovasc Med 2007; 4: 503-512.

4. Minakata K, Dearani JA, Nishimura RA, Maron BJ, Danielson GK. Extended septal myectomy for hypertrophic obstructive cardiomyopathy with anomalous mitral papillary muscles or chordae. J Thorac Cardiovasc Surg 2004; 127: 481-489.

5. Guo HC, Wang Y, Dai J, Ren CW, Li JH, Lai YQ. Application of 3D printing in the surgical planning of hypertrophic obstructive cardiomyopathy and physician-patient communication: a preliminary study. J Thorac Dis 2018; 10 867-873.

6. Hermsen JL, Burke TM, Seslar SP, Owens DS, Ripley BA, Mokadam NA, Verrier ED. Scan, plan, print, practice, perform: development and use of a patient-specific 3-dimensional printed model in adult cardiac surgery. J Thorac Cardiovasc Surg 2017; 153: 132-140.

7. Andrushchuk U, Adzintsou V, Nevyglas A, Model H. Virtual and real septal myectomy using 3-dimensional printed models. Interact Cardiovasc Thorac Surg 2018; 26: 881-882.

8. Song B, Dong R. Comparison of modified with classic Morrow septal myectomy in treating hypertrophic obstructive cardiomyopathy. Medicine (Baltimore) 2016; 95: e2326.

9. Cho YH, Quintana E, Schaff HV, Nishimura RA, Dearani JA, Abel MD, Ommen S. Residual and recurrent gradients after septal myectomy for hypertrophic cardiomyopathy - mechanisms of obstruction and outcomes of reoperation. J Thorac Cardiovasc Surg 2014; 148: 909-15.

10. Kuć M, Kołsut P, Różański J, Dąbrowski M, Kłopotowski M, Kumor M, Kowalski M, Kopyłowska N, Kuriata J, Kuśmierczyk M. Extended myectomy in the treatment of patients with hypertrophic obstructive cardiomyopathy. Kardiochir Torakochirurgia Pol 2016; 13: 300-304.

11. Smedira NG, Lytle BW, Lever HM, Rajeswaran J, Krishnaswamy G, Kaple RK, Dolney DO, Blackstone EH. Current effectiveness and risks of isolated septal myectomy for hypertrophic obstructive cardiomyopathy. Ann Thorac Surg 2008; 85: 127-133.

12. Maron BJ, Estes NA $3^{\text {rd }}$, Maron MS, Almquist AK, Link MS, Udelson JE. Primary prevention of sudden death as a novel treatment strategy in hypertrophic cardiomyopathy. Circulation 2003; 107: 2872-2875.

13. Tang B, Song Y, Cui H, Ji K, Yu Q, Zhu C, Zhao S, Wang S. Prognosis of adult obstructive hypertrophic cardiomyopathy patients with different morphological types after surgical myectomy. Eur J Cardiothorac Surg 2018; 54: 310-317. 
14. Ibrahim M, Rao C, Ashrafian H, Chaudhry U, Darzi A, Athanasiou T. Modern management of systolic anterior motion of the mitral valve. Eur J Cardiothorac Surg 2012; 41: 1260-1270.

15. Ferrazzi P, Spirito P, lacovoni A, Calabrese A, Migliorati K, Simon C, Pentiricci S, Poggio D, Grillo M, Amigoni P, Iascone M, Mortara A, Maron BJ, Senni M, Bruzzi P. Transaortic chordal cutting: mitral valve repair for obstructive hypertrophic cardiomyopathy with mild septal hypertrophy. J Am Coll Cardiol 2015; 66: 1687-1696.

16. Gutermann H, Pettinari M, Van Kerrebroeck C, Vander Laenen M, Engelen K, Fret T, Dion RA. Myectomy and mitral repair through the left atrium in hypertrophic obstructive cardiomyopathy: the preferred approach for contemporary surgical candidates? J Thorac Cardiovasc Surg 2014; 147: 1833-1836.

17. Dulguerov F, Marcacci C, Alexandrescu C, Chan KM, Dreyfus GD. Hypertrophic obstructive cardiomyopathy: the mitral valve could be the key. Eur J Cardiothorac Surg 2016; 50: 61-65.

18. Van der Merwe J, Casselman F, Van Praet F. Endoscopic Port AccessTM left ventricle outflow tract resection and atrioventricular valve surgery. J Vis Surg 2018; 4: 100.

19. Vriesendorp PA, Schinkel AF, Soliman OI, Kofflard MJ, de Jong PL, van Herwerden LA, Ten Cate FJ, Michels M. Long-term benefit of myectomy and anterior mitral leaflet extension in obstructive hypertrophic cardiomyopathy. Am J Cardiol 2015; 115: 670-675.
20. Tang Y, Song Y, Duan F, Deng L, Ran J, Gao Getal. Extended myectomy for hypertrophic obstructive cardiomyopathy patients with midventricular obstruction. Eur J Cardiothorac Surg 2018; 54: 875-883.

21. Liu Y, Song Y, Gao G, Ran J, Su W, Li H, Tang Y, Duan F, Sun H. Outcomes of an extended Morrow procedure without a concomitant mitral valve procedure for hypertrophic obstructive cardiomyopathy. Sci Rep 2016; 6: 29031.

22. Fukuhara S, Edwards S, Kurlansky P, Takayama H. Bimanual examination for septal myectomy for hypertrophic cardiomyopathy. Interact Cardiovasc Thorac Surg 2014; 19: 735-737.

23. Matsuzaki K, Tsukada T, Sato M, Watanabe Y. Transaortic septal myectomy using direct septal echography. Interact Cardiovasc Thorac Surg 2018; 26: 878-880.

24. Kim LK, Swaminathan RV, Looser P, Minutello RM, Wong SC, Bergman G, Naidu SS, Gade CL, Charitakis K, Singh HS, Feldman DN. Hospital volume outcomes after septal myectomy and alcohol septal ablation for treatment of obstructive hypertrophic cardiomyopathy: US Nationwide Inpatient Database, 2003-2011. JAMA Cardiol 2016; 1: 324-332.

25. Nguyen A, Schaff HV, Nishimura RA, Dearani JA, Geske JB, Lahr BD, Ommen SR. Does septal thickness influence outcome of myectomy for hypertrophic obstructive cardiomyopathy? J Thorac Cardiovasc Surg 2018; 53: 582-589. 